Revista da Seção Judiciária do Rio de Janeiro

\title{
UM DEBATE EM TORNO DAS RELAÇÕES ENTRE OS SISTEMAS DE PERSECUÇÃO PENAL E A PRODUÇÃO DA PROVA NA IDADE MÉDIA NA PERSPECTIVA DA DOUTRINA JURÍDICA
}

\section{A DEBATE ABOUT THE RELATIONS BETWEEN CRIMINAL PERSECUTION SYSTEMS AND THE PRODUCTION OF EVIDENCE IN THE MIDDLE AGES FROM THE PERSPECTIVE OF LEGAL DOCTRINE}

Alexandre Cesar dos Santos ${ }^{1}$

Resumo: O presente artigo aborda o tema da produção da prova nos sistemas de persecução penal em busca da verdade na Idade Média. A busca pela verdade sempre foi complexa e tem o objetivo de dirimir os conflitos judiciais. Os meios místicos de resolução de causas penais durante boa parte da Idade Média se deram pelas ordálias. Com a Magna Charta Libertatum tem-se o nascimento do processo penal moderno com a cláusula do devido processo legal, o qual busca limitar o arbítrio do Estado e a racionalidade para solução dos conflitos baseados em provas; Além disso, faz-se um estudo acerca dos sistemas inquisitivos, contraditório e adversarial na produção da prova. Procura-se apresentar de forma didática e clara como se dá a produção da prova nos sistemas de persecução penal da civil law e da common law para a busca da verdade. A metodologia da pesquisa utilizada no estudo é a bibliográfica que se debruça sobre o tema. Nessa perspectiva, demonstra-se que a busca pela verdade na persecução penal vai aos poucos se afastando do misticismo medieval e se aproximando da racionalidade na produção da prova para a solução dos litígios, com os sistemas de persecução penal para legitimar a justiça criminal como o acertamento da verdade.

Palavras-chaves: Persecução penal. Sistema. Prova. Verdade. Devido processo penal.

Abstract: This article addresses the issue of evidence production in criminal prosecution systems in search of truth in the Middle Ages. The search for the truth has always been complex and aims to resolve legal conflicts. The mystical means of solving criminal causes during much of the Middle Ages took place through ordeals. With the Magna Charta Libertatum, the modern criminal procedure was born with the clause of due legal process, which seeks to limit the State's discretion and the rationale for the solution of conflicts based on evidence; In addition, a study is made about the inquisitive, contradictory and adversarial systems in the production of

\footnotetext{
${ }^{1}$ Delegado de Polícia Civil do Estado de Alagoas. Mestrando em Direito Público pela Universidade Federal de Alagoas. Bacharel em Direito pela Universidade Federal de Pernambuco- UFPE (2006). Pós-graduado em Ciências Penais pela Universidade Anhanguera-Uniderp - LFG. Pós- graduado em Direitos Humanos e Segurança Pública pela Universidade de Federal de Rondônia/SENASP.
} 
Revista da Seção Judiciária do Rio de Janeiro

evidence. It seeks to present, in a didactic and clear way, how evidence is produced in the civil law and common law criminal prosecution systems for the search for the truth. The research methodology used in the study is the bibliographical that focuses on the theme. From this perspective, it is demonstrated that the search for truth in criminal prosecution is gradually moving away from medieval mysticism and approaching rationality in the production of evidence for the solution of disputes, with criminal prosecution systems to legitimize criminal justice such as the correctness of the truth.

Keywords: Criminal persecution. System. Test. Truth. Due criminal process.

Recebido em: $15 / 10 / 2021$ Aceito para publicação em: 12/11/2021 
Revista da Seção Judiciária do Rio de Janeiro

\section{INTRODUÇÃO}

O presente artigo destaca a relação dos sistemas de persecução penal com a produção da prova em busca do acertamento da verdade fática que se desenvolveu durante a idade medieval na Europa continental e na Inglaterra. Nesse contexto histórico, o estudo vai permitir compreender como eram utilizados os instrumentos e os métodos das colheitas das provas para a resolução de conflitos judiciais na seara criminal.

Considerando essa perspectiva, a problemática deste artigo científico gira em torno das diferenças dos sistemas probatórios na persecução penal, notadamente, em face da prova para demonstrar a realidade fática nos sistema jurídicos da civil law e da common law. Por essa razão, esse sucinto trabalho vai apresentar quais os motivos e com se deram a passagem pela busca da verdade na Idade Média, o fim das ordálias, introdução da cláusula do devido processo legal e o inquérito nos sistemas probatórios para a resolução dos litígios.

Sendo assim, o objetivo desse artigo é perquirir acerca dos sistemas de provas para compreender a sua evolução durante a Idade Média na Europa continental e na Inglaterra, que aos poucos foi se afastando dos misticismos das ordálias, passando pelas técnicas do inquérito da Igreja, que empregava a tortura para obter confissão, até chegar à racionalidade e à ritualização em busca da verdade, com o advento das ideias liberais filosóficas do Iluminismo.

Por isso, a relevância do tema se justifica em virtude de apresentar os sistemas probatórios inquisitivo, contraditório e adversarial na produção da prova pela perspectiva jurídica e suas relações históricas. Dessa maneira, demonstra-se que os sistemas de persecução penal têm uma íntima relação com a produção e com o regramento da prova penal para o acertamento da verdade.

Por fim, para alcançar esses resultados, a pesquisa desenvolve-se pela metodologia bibliográfica, com reflexões de vários autores com suas propostas 
Revista da Seção Judiciária do Rio de Janeiro

teóricas em torno do tema tratado. Por isso, a abordagem dos tópicos é estruturada com fontes históricas e doutrinárias no âmbito das Ciências Jurídicas, que retratam os sistemas jurídicos de probatórios da civil law e da common law em torno da busca da verdade para resolver os litígios criminais.

\title{
2 DOS ORDÁLIOS AO INQUÉRITO EM BUSCA DO ACERTAMENTO DA VERDADE
}

A transição da Antiguidade para a Idade Média na Europa se deu, entre outros fatores, com a desagregação do Império Romano. ${ }^{2}$ Neste contexto, há uma ruptura da estrutura política de poder centralizado para uma nova formação de poder fragmentado, como explica Paolo Grossi (2014, p. 53):

\begin{abstract}
A ordem política medieval tem sua inauguração histórica quando, no século IV, se inicia uma profunda crise do Estado imperial, contida e reprimida a custo até a época de Diocleciano, mas que a partir de então desemboca em manifestações cada vez mais relevantes: crises de efetividade, de autoridade, de credibilidade. No mundo pós-Diocleciano resta apenas um Estado-crisálida, incapaz de afirmar a própria vontade, mas sobretudo incapaz de expressar aquela vontade unitária, substitutiva e intolerante, de volições particulares concorrente, que é característica de toda estrutura genuinamente estatal; ou seja, resta uma não Estado. O Estado romano morre, morre por inanição, por desgastes interno que é material e espiritual, por vazio de poder eficaz e de programa planejado.
\end{abstract}

Em termos estruturais, a ordem jurídica medieval nasce esparsa e fragmentada com elementos políticos e culturais dos romanos, germânicos e

\footnotetext{
${ }^{2}$ Geralmente consideram-se as Invasões Bárbaras como ponto divisório entre o Mundo Antigo e o Mundo Medieval. Essa divisão tradicional não levam em conta as transformações nas relações econômica e sociais como ponto de partida para a compreensão do processo histórico, mas acontecimentos políticos com balizamentos. "Usam-se como pontos de referências para assinalar o início da Idade Média a transferência da Capital do Império Romano para Constantinopla (330), a Batalha de Andrinopla em que os visigodos derrotaram os romanos e se instalaram em massa no Império (378), a divisão do Império Romano em Oriente e Ocidente por Teodósio (395) ou o fim do Império Romano do Ocidente, quando deposto o último Imperador, Rômulo Augústulo (476). Acrescente-se a invasão da Península Ibérica pelos Muçulmanos (711), separando ainda mais a Europa Ocidental da Oriental". AQUINO, Rubim Santos Leão de; FRANCO, Denize de Azevedo; LOPES, Oscar Guilherme Pahl Campos. História das Sociedades: das comunidades primitivas às sociedades medievais. Rio de Janeiro: Editora ao Livro Técnico, 1980. p. 286.
} 
Revista da Seção Judiciária do Rio de Janeiro

orientais, o que propiciou um pluralismo jurídico. Com efeito, entre os Séculos III e VIII, as normas jurídicas eram preponderantemente de natureza consuetudinária, mas havia compilações que imitavam as codificações Imperiais Romanas:

\begin{abstract}
São exemplos delas as leges visigothorum, dos reinos visigodos de França e da Península Ibérica; a lex baiuvariorum, dos bávaros do Sul da Alemanha; a lex borgundionum, dos brunidos ou borgonheses do Leste da França; a lex salica, dos francos; o Edito de Rotário, dos lombardos, etc. (HESPANHA, 2012, p. 132).
\end{abstract}

Isso é resultado dos contatos entre esses povos e o Mundo Romano, que se intensificaram com as "migrações bárbaras", que comumente são denominadas pejorativamente como "invasões bárbaras". De fato, essa expressão não é correta, uma vez que foram movimentos de populações, migrações de povos inteiros, nos séculos IV e $V$, que se instalaram em territórios romanos, o que precipitou a desintegração do Império Romano em vários Reinos independentes, dominados por "aristocracias romano-germânicas". As razões dessas imigrações, entre outras, foi à busca de novas terras para cultivo e, sobretudo, para a criação de gado, além de saques das riquezas existentes no Império Romano. (AQUINO; FRANCO; LOPES, p. 297).

Segundo Taruffo (2016, p. 16-17), a entrada de novas populações com suas famílias, servos, costumes e tradições jurídicas levaram à sociedade europeia a uma profunda e duradoura confusão. Neste cenário, os "guerreiros bárbaros" trouxeram um instrumento muito importante, que era utilizado para resolver controvérsias de qualquer tipo: os ordálios. Ainda, segundo o autor italiano, "os ordálios têm uma história antiga e obscura: provavelmente chegaram da Índia à Europa central, onde foram adotados pelos povos germânicos. Mas, segundo Bartlett, os ordálios foram características dos povos Francos; não de todos os povos germânicos."

Considerando esse contexto, o sistema germânico dos ordálios difundiu-se por todo continente europeu a partir do final do século IV e tornou-se o mais comum 
Revista da Seção Judiciária do Rio de Janeiro

sistema probatório, para dirimir as controvérsias penais ou, em muitos casos, civis, uma vez que essa distinção jurídica não era exatamente clara. Cabe destacar que os ordálios eram uma grande variedade de técnicas utilizadas em diversas situações, que variavam de acordo com os costumes e as tradições peculiares, que os juízes e as partes escolhiam. Dentre eles, o mais comum e duradouro foi provavelmente 0 duelo judicial, em que as partes ou seus campeões combatiam na presença dos juízes. Porém, havia outras formas muito populares, entre elas: a prova d'água, a prova do caldeirão fervente, a prova do ferro incandescente, a prova do fogo, e tantos outros cruéis. Todos esses meios de provas eram denominados vulgarmente de "juízos divinos", uma vez que se fundavam na premissa de que Deus era chamado a assistir às partes que estavam em litígio. Assim, Deus deveria determinar a evidência do sujeito inocente ou culpado, conforme o êxito da prova. Essa base empírica dos ordálios se consolidou na Europa continental, depois da conversão das tribos germânicas à religião católica. Nesta toada, um sacerdote deveria sempre assistir ao ordálio e santificar quais os instrumentos que deveriam ser utilizados para a realização (TARUFFO, 2016, p. 19-20).

Assentadas essas premissas, é comum que haja correntes de historiadores considerem as práticas dos ordálios como meios de provas irracionais nas sociedades medievais. Ora, em uma concepção moderna e com o desenvolvimento dos direitos e das garantias fundamentais já consagradas nas Cartas Políticas do pós-Segunda Guerra Mundial, certamente que sim. Contudo, Michelle Taruffo sustenta o contrário desse estereotípico medievalista, posto que é um erro querer interpretar os eventos passados de acordo com os critérios modernos. Desse modo, para o autor italiano, os ordálios podem parecer culturalmente racionais, durante a Idade Média, já que tinham sentidos coerentes com as culturas sociais naqueles tempos, em que, a vida cotidiana das pessoas era dominada pelo sangue e pela violência, além disso, era um período de um mundo místico repleto de milagres, santos, demônios, bruxas e magos. Neste contexto histórico, não havia qualquer aberração em pensar que Deus 
Revista da Seção Judiciária do Rio de Janeiro

pudesse intervir na determinação do êxito nas controvérsias judiciais. Isso explica o lado da funcionalidade racional, seu caráter sacramental e sua popularidade pela difusão da fé religiosa, além do fato de ter perdurado por vários séculos na formação probatória da prática judiciária em quase toda a Europa (TARUFFO, 2016, p. 22).

No mesmo sentido, Aquino, Franco e Lopes (p. 296), argumenta que a sociedade Europeia sofreu transformações com as populações germânicas, dentre elas, o Direito costumeiro, as penas rigorosas, a vingança coletiva, as penas pagas através de indenizações (Wergeld) ${ }^{3}$, nos julgamentos de pisar em brasas e sofrer queimaduras, que eram os ordálios. Por outro lado, em termos de estruturas sociais, ocorreu a passagem do escravismo para o Feudalismo e o fortalecimento da Igreja Católica no curso da Idade Média.

Neste cenário, os povos germânicos eram animistas, ou seja, adoravam as forças da natureza e manifestavam suas divindades por meio de sinais físicos, os facilmente perceptíveis, para clarear o caminho a seguir para dirimir seus conflitos e fazer justiça. Por outro lado, as autoridades judiciárias eclesiásticas exerciam as suas funções pela "busca da verdade real" pela reconstrução histórica dos fatos, baseado no conhecimento, portanto, considerado para a Idade Média, mais evoluído.

Ainda é necessário esclarecer que os ordálios eram compreendidos como uma técnica residual, destinados a decidir controvérsias quando os meios de provas, para apurar a verdade, eram insuficientes ou não estavam disponíveis para dirimir as dúvidas acerca dos fatos. Assim, por esse espectro, os ordálios não eram

\footnotetext{
${ }^{3}$ O Wergeld era uma prática jurídica dos germanos em virtude da qual o culpado de um delito, ou seus parentes, era obrigado ao pagamento de uma soma em dinheiro à vítima os aos seus parentes. Era o "preço do homem" que, não sendo pago, poderia levar a um conflito entre as famílias da vítima e do culpado. Pela lei dos francos, "a multa pelo assassinato de um servidor real era o triplo da de um homem comum. As mulheres livres e as nobres também tinham Wergeld específico. Este era menor que o de um homem livre ou de um nobre, e o valor da vida da mulher era automaticamente reduzido se ela se cassasse com um cidadão de condição inferior". SIMONS, G. Os Bárbaros na Europa. Biblioteca da Historia Universal Life. Livraria José Olympio, p. 84, apud AQUINO, Rubim Santos Leão de; FRANCO, Denize de Azevedo; LOPES, Oscar Guilherme Pahl Campos. História das Sociedades: das comunidades primitivas às sociedades medievais. Rio de Janeiro: Editora ao Livro Técnico, 1980. p. 300.
} 
Revista da Seção Judiciária do Rio de Janeiro

compreendidos como meios de provas em sentido estrito, isto é, como um instrumento para apurar a verdade sobre os fatos que irão fundamentar a decisão do julgador. Na verdade, os ordálios funcionavam como um instrumento para resolver os conflitos de forma célere e definitiva nos casos de incerteza nas sociedades medievais.

Conforme explica Geraldo Prado (2006, p. 78-80), evidentemente que o processo penal germânico da antiguidade era eminentemente consuetudinário, fundados nos princípios da moral, e não distinguia entre ilícitos civil e penal, o que influenciou o direito no continente europeu, inclusive em áreas antes dominadas, pelo Império Romano, chegando a Portugal e a Espanha, o que passaram lentamente a incorporar e assimilar o direito Romano-Canônico e à introdução da inquisição. Isso fez com que houvesse influências recíprocas das culturas e dos direitos entre esses povos devido à convivência lado a lado de sistemas para a solução de conflitos em litígios. Entretanto, na primeira parte da Idade Média, o aparato judicial germânico foi cedendo espaço para a jurisdição eclesiástica, a qual teve seu poder centralizador e eficiente. Neste contexto, a Igreja passou a ver no delito não apenas uma questão de interesse privado, mas, sobretudo, um problema da salvação da alma como uma maneira de expiação da culpa.

É evidente ainda que a Igreja passou a investigar um grande número de delitos, o que sedimentou seu poder nos processos inquisitoriais na busca da verdade. Daí a substituição dos duelos dos "reinos bárbaros" pelo modelo inquisitorial implantado pela justiça laica, o que levou ao fortalecimento das monarquias, e, como consequência, a formação do Estado-Nação. Sob esse enfoque, Geraldo Prado (2006, p. 81) aduz de forma sintética a consolidação do sistema inquisitório:

A remanescente estrutura acusatória, no entanto começa a render-se a aspectos quase sempre identificados no procedimento inquisitório, tais como a forma escrita da dedução da acusação e o segredo que envolvia a produção da prova testemunhal, chegando, pois, ao emprego da tortura, a culminância das presunções e da confissão. 
Revista da Seção Judiciária do Rio de Janeiro

Por sua vez, Michel Foucault (2002, p. 69) destaca que "o inquérito na Europa Medieval é sobretudo um processo de governo, uma técnica de administração, uma modalidade de gestão; em outras palavras, o inquérito é uma determinada maneira do poder se exercer". Percebe-se, portanto, que o sistema de persecução penal inquisitorial, a cargo da Igreja Católica, era colocar um instrumento regrado normativamente, de forma escrita e eficaz que pudesse substituir o caráter arbitrário dos duelos bárbaros para se buscar a "verdade absoluta" na seara criminal.

Como isso, a Igreja Católica durante a Idade Média teve um papel fundamental na dogmática jurídica, já que estabeleceu as regras escritas, as quais são as fontes do Direito Canônico, bem como foi a responsável com exclusividade pelo direito privado, a exemplo de casamentos, testamentos, juramentos não cumpridos, e o julgamento de outras causas pelos tribunais eclesiásticos, como heresias, simonias, sacrilégios, apostasias, feitiçarias, etc. (CASTRO, 2006, p. 133-134). Neste contexto, é emblemático para constar que, até meados do século XIII, os sistemas probatórios na seara penal eram irracionais do ponto de vista da doutrina penal clássica, pois eram baseados nas divindades, nos duelos e nas ordálias, na busca da verdade absoluta para a solução dos litígios.

Considerando essas breves linhas históricas, é de se ver que a produção da prova é um fenômeno que varia no tempo e no espaço, sendo intimamente ligado por circunstâncias culturais e políticas, mas sempre voltada à formação do convencimento do juiz e diretamente vinculada aos sistemas persecução penal.

\section{O DEVIDO PROCESSO LEGAL: UMA GARANTIA FUNDAMENTAL NA BUSCA DA VERDADE}

É inegável que as instituições político-jurídicas e sociais da Europa Continental, nos Séculos IV e V, estavam organizadas em vários Reinos, ${ }^{4}$ entre

\footnotetext{
${ }^{4}$ Em aperto de síntese: com a desestruturação do Império Romano, a organização social e política da Europa passaram a compor vários reinos, dentre eles: Os Vândalos (429-534) que ocuparam parte da Península Ibérica e norte da África, eles eram adeptos às heresias do arianismo, perseguiam os 


\author{
romanos e germanos, o que levou à adoção de inúmeras Leis para submeter \\ populações diferentes, como explica Jacques Le Goff $(1999$, p. 36):
}

\begin{abstract}
Se a necessidade de codificação e elaboração de leis fosse ótimo, especialmente entre os bárbaros, também parecia necessário para os vários soberanos bárbaros uma nova legislação que visa aos Romanos. Geralmente eram adaptações e simplificações do código de Teodósio, de 438. Assim, apareceu o Breviário de Alarico (506) entre os visigodos e a Lex Romana burgundiorum, entre os Borgonheses. A diversidade jurídica não era tão grande como se poderia acreditar, em primeiro lugar porque as leis bárbaras dos vários povos se pareciam muito, então, porque, em cada reino um Código tinha tendência de vencer pela mão dos outros e, finalmente, porque o traço romano, mais ou menos claro desde o início, por exemplo, entre os visigodos, tendia a ser evidente em vista de sua superioridade. A influência da Igreja, especialmente após a conversão dos reis arianos e as tendências unificadoras dos Carolíngios no final do século VII e início do século XIX, contribuiu para uma regressão ou desaparecimento da personalidade das leis em benefício de sua territorialidade. Desde o reinado do Visigodo Recesvinto (649-672), por exemplo, o clero pressionou o soberano para publicar um novo Código aplicável tanto aos visigodos quanto aos romanos. ${ }^{5}$ (tradução livre).
\end{abstract}

cristãos fiéis da doutrina da Igreja de Roma. Os Ostrogodos (493-553) fixaram-se na Macedônia e ocuparam a Itália. Os Visigodos (419-711) iniciaram a ocupação da Gália e da Península Ibérica por volta do ano 419. Os Burgúndios (443-534) povos de origem escandinava estabelecidos na região do Rio Reno, mas em 534 foram anexados pelos francos. Os anglos, saxões e jutos (450-1065) fundaram sete reinos na Grã-Bretanha: Essex, Wessex, Sussex, Kent, East-Anglia, Northumbria e Mércia. Em 866 começou a ocupação da Inglaterra pelos danos ou dinamarqueses, povos vikings, que, pouco a pouco, expandiram sua conquista, constituindo o Danelag. Conforme: ARRUDA, José Jobson de A. História

Antiga e Medieval. 9. ed. São Paulo: Ática, 1986. p. 318-323.

5 "Si la necesidad de codificación y de redacción de las leyes era grande, sobre todo entre los bárbaros, también les pareció necesaria a varios soberanos bárbaros una nueva legislación destinada a los romanos. Por lo general fueron adaptaciones y simplificaciones del código de Teodosio, del 438. Así aparecieron el Breviario de Alarico (506) entre los visigodos y la Lex romana burgundiorum, entre los burgundios. La diversidad jurídica no fue tan grande como se pudiera creer,en primer lugar porque las leyes bárbaras de los diversos pueblos se asemejaban mucho, después porque en cada reino un código tenía tendencia a ganar por la mano a los demás y, por último, porque la huella romana, más o menos clara desde el principio «por ejemplo entre los visigodos» tendía a quedar de manifiesto en vista de su superioridad. La influencia de la Iglesia, sobre todo después de la conversión de los reyes arríanos y las tendencias unificadoras de los carolingios a finales del siglo VIII y comienzos del siglo IX contribuyeron a una regresión o a una desaparición de la personalidade de las leyes en beneficio de su territorialidad. Desde el reinado del visigodo Recesvinto (649-672) por ejemplo, el clero presionó al soberano para que publicara un nuevo código aplicable tanto a los visigodos como a los romanos". GOFF, Jacques Le. La civilización del occidente medieval. Barcelona: Editorial Paidós, 1999. p. 36.

Revista Auditorium, Rio de Janeiro, v. 25, n. 53, p. 149-179, nov. 2021/fev. 2022 
Revista da Seção Judiciária do Rio de Janeiro

Por seu turno, no ano de 1215 em Roma, o Papa Inocêncio III impôs, no IV Concílio de Latrão, a proibição dos ordálios e dos sacerdotes de participarem deles. Isso significava na prática que a Igreja não poderia mais se envolver em demandas jurídicas, sob o argumento que não se pode desafiar Deus a intervir em questões mundanas para conceber se uma parte merecia vencer ou perder uma demanda jurídica, bem como determinar uma vitória do inocente e a derrota do culpado. (TARUFFO, 2016, p 18-19).

Entretanto, há outras explicações para o desinteresse pela procura das ordálias, juízos de Deus, para a solução de conflitos judiciais, que aos poucos foram desaparecendo pela Europa Ocidental, sendo o banimento no século XIV. Uma delas é o crescimento econômico e do desenvolvimento do comércio, o que fez surgir à procura pela certificação documental dos negócios no final do século XII, o que dava segurança jurídica (ROBERTO, 2011, p. 36-37).

Como já sedimentado na literatura das Ciências Jurídicas, o ano de 1215, também foi um momento histórico simbólico muito importante, primeiramente, para o desenvolvimento do sistema jurídico da common law, que tiveram reflexos sensíveis no curso da persecução penal, uma vez que a partir dessa cláusula consagrou-se o habeas corpus, o tribunal do júri para a resolução de conflitos, bem como, inúmeros princípios processuais penais, dentre eles: a reserva e jurisdição, o princípio do contraditório e da presunção de inocência. Esse fato se deu em Londres, quando o Rei João Sem Terras foi forçado por seus Barões a conceber a Magna Charta Libertatum, o que deu início a uma gama de garantias formais aos acusados em geral em face ao poder do Estado e um sistema processual em que os pares deveriam desempenhar o papel de juízes do fato.

Algumas indagações se colocam sobre esse momento histórico do século XII: será que a partir da Magna Charta Libertatum tem-se o nascimento do processo penal moderno? Para a maioria da doutrina, esse documento em seu artigo 39, proclama-se, ainda que de forma embrionária, solenemente o due process of law, ou 
seja, o devido processo legal. Dessa maneira, tem-se a fonte do fundamento das garantias de direitos individuais, hoje consagrados na maioria das Cartas Políticas, que envolvem valores de vida, da liberdade e de propriedade dentro do sistema da common law. No entanto, Carvalho (2004, p. 126) alerta que:

\begin{abstract}
A expressão devido processo legal, o que só veio a ocorrer em 1354 , sob o reinado de Eduardo III, em lei aprovada pelo Parlamento Inglês, na forma due processo of law. Mas sempre se entendeu que a locação law of the land significava o mesmo que due process of law, tendo esta sido consagrada como sucessora daquela, com idêntico teor, tanto pelas cortes inglesas como pelas norte-americanas. Da Inglaterra, passou o devido processo legal às colônias americanas, tendo várias delas positivado o princípio em suas Constituições, por volta dos anos 1776 e 1777. Somente, após a independência dos Estados Unidos, é que este país incorporou-o em sua Constituição, na $5^{a}$ emenda. Foi Justamente nos Estados Unidos que o devido processo legal atingiu o ápice de sua elaboração doutrinária e jurisprudencial.
\end{abstract}

Sob essa ótica, Tucci (2002, p. 205) a partir da concepção americana, conceitua: "o devido processo legal se apresenta como um conjunto de elementos indispensáveis para que possa atingir, devidamente, a sua já aventada finalidade de litígios (em âmbito extrapenal) ou solucionadora de conflitos de interesses de alta relevância social (no campo penal)."

Considerando essa perspectiva, Ada Pellegrini Grinover (1978, p. 137) defende que o due processo of law é um conjunto de garantias constitucionais do processo, as quais tutelaram os direitos processuais das partes em litígio, o que deu ao processo judicial uma configuração "não apenas técnica, mas também ético política". Por seu turno, Tucci (2002, p. 205) acentua que:

A partir da concepção, a garantia do devido processo legal compreende uma série de elementos combinados que asseguram uma determinada forma de processo em torno de valores de equidade, imparcialidade, independência, igualdade, publicidade, racionalidade, certeza e universalidade, a par de outros requisitos específicos na Constituição. 
Revista da Seção Judiciária do Rio de Janeiro

Percebe-se que, por essa linha de raciocínio, o Estado passa a tutelar a administração da justiça penal como uma função de poder-dever de, ao aplicar lei penal, abster-se dos abusos das autoridades processantes e, ao mesmo tempo, estabelecer os limites no campo procedimental para a realização do Direito Penal com a aplicação da pena. Isso por que os Estados Absolutistas da Europa Continental adotaram o sistema probatório inquisitivo com o propósito de repressão da criminalidade no corpo social e, por outro lado, a Igreja Católica com a Santa Inquisição para reprimir as práticas de novas crenças consideradas heréticas, que se desviassem dos dogmas estabelecidos pela Igreja (KHALED JÚNIOR, 2016, p. 63).

Tomando-se como premissas as estruturas de bases do movimento Iluminista do século XVIII para humanizar a captação da prova com eficiência e garantias para aplicação das penas proporcionais ao delito ou absolver um inocente, os sistemas de provas buscam a legitimidade da justiça no acertamento da verdade fática. Por isso, não fora de propósito que a falibilidade humana dava lugar aos poucos à racionalidade aos sistemas processuais probatórios com a criação de regras de organização com o objetivo de superação do divino para resolução dos litígios.

Como se depreende, o processo penal moderno tem as raízes ideológicas pautadas nos direitos da liberdade que foram fincadas na filosofia Iluministas do século XVIII, a partir das ideias liberais francesas. Neste cenário, estabeleceram princípios no saber jurídico que combatiam e questionavam as práticas de abusos no âmbito do direito penal do Antigo Regime Absolutista, que era, em grande parte, com fundamentos em dogmas religiosos. De um modo geral, são lançados os fundamentos jurídicos que dão alicerces à igualdade jurídica, à racionalidade, à legalidade penal e à humanidade do Direito Penal, bem como estabelece a definição de delito e o quanto de punição. Vale dizer ainda que as influências da filosofia jusnaturalista, também, tiveram um peso importante na inauguração dos paradigmas legitimadores do direito penal humanitário que se estabeleceram no ocidente 
Revista da Seção Judiciária do Rio de Janeiro

europeu para racionalizar a pretensão punitiva do Estado, através de um processo criminal pautado em provas (PAULO, 2009, p. 156-163).

Essas características são do movimento iluminista que, no direito penal, tiveram uma grande influência na obra Dei delitti e delle pene (Dos delitos e das penas), em 1764, escrita por Cesare Bonesana, conhecido por marquês de Beccaria. Dessa maneira, no âmbito da persecução penal, é possível afirmar que se buscava a segurança jurídica do cidadão através do princípio da legalidade penal e os respeitos às garantias fundamentais negativas, ou seja, uma não intervenção do Estado nas relações individuais e sociais. Essa noção de garantia no plano jurídico, eram reflexos da ideologia do Estado liberal burguês na Idade Moderna que tinha como objetivo limitar o poder do soberano, notadamente nos processos criminais e na aplicação das penas aflitivas. Em outros termos, a visão filosófica de Beccaria são as vigas mestras do direito penal moderno, entre elas, os princípios da legalidade e da reserva legal para a definição de tipo penal e da aplicação das penas, como princípios orientadores da justiça criminal, materializados no devido processo legal.

Cabe ainda enfatizar que, com a consolidação dos Estados Modernos na Europa e do Constitucionalismo, a persecução penal assume princípios de legalidade, utilização dos meios racionais da prova e deixam para o passado, ao menos em tese, a tortura, as prisões arbitrárias, as penas desproporcionais ao delito, as condenações sem provas que norteavam o autoritarismo medieval. Portanto, é possível afirmar que realmente o processo penal moderno, baseado no sistema acusatório, com a adoção de procedimentos e julgamentos públicos para realização da justiça, traz racionalidade para a justiça criminal (MACHADO, 2009, p. 22-23).

Por essa razão, a cláusula do due process of law está entrosada com o Estado de Direito Constitucional, já que tem uma abrangência nos atos das esferas do poder de governo nos campos político e social. Desse modo, trata-se de um princípio de natureza constitucional que irradia por todos os ramos do Direito, sendo no processo penal, o direito ao contraditório, a ampla defesa, bem como um 
Revista da Seção Judiciária do Rio de Janeiro

processo justo perante um juiz imparcial, por exemplo. Sob esse prisma Valdir Sznick (2002, p. 21) enfatiza o devido processo legal:

\begin{abstract}
Assim, pode-se entender o devido processo legal como uma instituição na qual, pela norma, deve ser assegurada no processo, legalmente instituído, a oportunidade de ser ouvido por um tribunal competente pré-estabelecido, imparcial e independente, nas pretensões e manifestações das partes, com provas e documentos, permitindo uma defesa completa (ampla) sendo um padrão (standard), no processo como no direito material, limitando o direito do Estado, observando o princípio da igualdade (equal protection of the law).
\end{abstract}

Trazendo esse pensamento de processo penal moderno, sua concretização está na tutela do direito de ação e do processo para a realização da justiça e da preservação do valor liberdade. Diante disso, o due processo of law é uma fórmula de limitação do poder arbitrário do Estado em sede jurisdicional, administrativa ou legislativa, o que vai constituir o Estado Democrático de Direito com todo seu conjunto de direitos e garantias fundamentais.

Com efeito, a garantia do devido processo legal desdobra-se em um riquíssimo conjunto de outras normas que formam o arcabouço da ordem jurídica criminal de onde derivam diversos corolários de regras e princípios constitucionais garantistas, os quais legitimam a própria persecução penal. Fundando-se nesses princípios constitucionais garantistas, encontram-se os princípios do contraditório na produção da prova, da ampla defesa, de não produzir prova contra si mesmo e da paridade de armas, consagrados no processo penal moderno.

Daí que Alexandre Morais da Rosa (2004, p. 86-87) observa que o garantismo penal tem suas raízes nas ideias na filosofia iluminista e está voltado para a garantia dos direitos fundamentais, bem com no controle do poder do Estado em todas as suas esferas de atuação para estabelecer limites ao seu próprio poder de punir em face aos direitos fundamentais:

O garantismo jurídico esteia-se assim, na tradição iluminista, articulando mecanismos capazes de limitar o poder soberano, que sofre as influências 
Revista da Seção Judiciária do Rio de Janeiro

\begin{abstract}
dos acontecimentos históricos, notadamente, o "levante neoliberal", que põe em risco as garantias individuais. Esta limitação ao poder não se dá apenas em relação ao Executivo, mas a todas as funções estatais, destacando-se a limitação ao Legislativo, vinculado que está aos direitos fundamentais, e limitado, de forma que nem mesmo a vontade da maioria pode negar ou violar os direitos fundamentais.
\end{abstract}

Daí a conclusão que o processo penal não pode ser considerado apenas um instrumento de persecução do imputado na perspectiva do estado democrático de direito . Assim, entende Ada Grinover Pellegrini (1982, p. 20):

\footnotetext{
É dentro do processo penal, entendido como instrumento da persecução penal, que a liberdade do indivíduo avulta e se torna mais nítida a necessidade de se colocarem limites à atividade jurisdicional. A dicotomia defesa social-direitos de liberdade assume frequentemente conotações dramáticas no juízo penal; e a obrigação do Estado de sacrificar na medida menor possível os direitos de personalidade do acusado se transforma na pedra de toque de um sistema de liberdades públicas.
}

Apontada essas nuances, percebe-se a Magna Charta Libertatum é a gênese do devido processo legal que, no correr da história, foi aos poucos limitando o poder punitivo arbitrário do Estado nos sistemas de provas, com racionalidade para legitimar a justiça penal e se afastando do misticismo das ordálias e do poder divino. É por essa razão que os sistemas probatórios são modelos que estão em evolução constante na busca de regramentos acerca da produção da prova, com seus métodos próprios para o acertamento da verdade para fazer a justiça.

\title{
4 SISTEMAS DE PERSECUÇÃO PENAL: CONDIÇÃO SINE QUA NON EM BUSCA DA VERDADE NO DEVIDO PROCESSO LEGAL
}

Devido às peculiaridades e às características dos sistemas de persecução penal, a doutrina processualista contemporânea faz uma divisão clara e didática entre os sistemas inquisitivo e acusatório, os quais são sistema probatórios jurídicos do mundo ocidental formados pelas as famílias jurídicas romano-germânico e a 
Revista da Seção Judiciária do Rio de Janeiro

common law. Essa dicotomia é tomada como modelos em que se desenvolveram em momentos de contexto históricos e culturais distintos, em que cada sistema possui seus princípios reitores do ponto de vista teórico predominante de garantias processuais.

Porém, sem perder de vista as características peculiares dos sistemas jurídicos de persecução penal, Paolo Grossi (2014, p. 30) faz uma observação:

\begin{abstract}
No âmbito histórico, parece-nos que se pode falar de "experiência jurídica medieval" e de "experiência jurídica moderna". No âmbito positivo, é correto identificar uma experiência jurídica de commom law (referente aos países anglo-saxões) e uma experiência jurídica de civil law ( referente aos países da Europa continental e também da América Latina, todos com regime jurídico codificado).
\end{abstract}

Além dessa base teórica, conforme Hélio Tornaghi (1980, p. 9-10), historicamente, o sistema acusatório era conhecido em toda antiguidade, desde a Grécia antiga e o período Republicano Romano, com características preponderantes a oralidade e publicidade. Por outro lado, o sistema de persecução inquisitório surgiu como subsidiário do acusatório na época da República em Roma, ao tempo de Diocleciano. Foi instituída a figura dos quaesitores que eram encarregados de investigar e denunciar os crimes para evitar a impunidade, enquanto a forma inquisitória o sigilo e a escrita dos atos. Por outro lado, o autor adverte que os sistemas de processo penal se apresentam, através da história, sob três formas distintas: acusatória, inquisitória e mista. Na forma acusatória, as funções de acusar, defender e julgar estão atribuídas a órgãos distintos, enquanto no sistema inquisitório estão confinados ao mesmo órgão. Entretanto, é errado atribuir ao processo inquisitório às características do sigilo e da escritura, enquanto ao processo acusatório a oralidade e a publicidade.

O processo inquisitório surge na verdade de uma exigência de "cientificidade" relativamente para substituir o rito da "ordália" do juízo divino na busca da verdade a ser alcançada pelo Juiz-Acusador. Neste contexto, o processo 
Revista da Seção Judiciária do Rio de Janeiro

acusatório perturbava a busca da verdade, o que se busca a confissão do imputado a qualquer custo como prova privilegiada que vai dirimir a raiz do conflito. Diante, dessa sistemática, a tortura é plenamente justificada no rito inquisitório, que não era entendida como pena, mas instrumento ad eruendam veritatem, ou seja, instrumento para se descobrir a verdade (BETTIOL; BETTIOL, 2008, p. 166).

Para evitar que os humildes fossem vítimas dos poderosos e que os homens de bens sofressem com a exposição de suas intimidades, bem como para segurar o bom êxito das investigações, o processo passou a ser secreto e documentado pela redução à escrita de todos os atos. O juiz detinha os mais amplos poderes de investigação, longe para satisfazer a verdade ficta, para apurar os fatos em sua materialidade, após passava-se à responsabilidade do suspeito (GRINOVER, 1982, p. 33).

O segredo na busca pelas provas, o emprego da tortura para obter confissão e a concentração de poder nas "mãos" dos julgadores transformaram o processo inquisitório em instrumento perigoso e que não oferecia segurança jurídica aos imputados. Desse modo, as arbitrariedades no curso do processo criminal eram constantes com o objetivo de obter a confissão da culpabilidade pelo suspeito, a todo custo. Como explica Khaled Júnior (2016, p. 64): "a busca obsessiva - e patológica pela verdade é uma característica marcante do sistema inquisitório, o que é facilmente observável através da compreensão dos mecanismos utilizados para sua produção".

O modelo inquisitorial tem início no século XII e se consolidou na Europa Continental no século XVI, com exceção da Inglaterra. Esse sistema probatório serviu como um dos instrumentos de formação e consolidação do Estado Absolutista, já que era utilizado como método de controle social. Para época do apogeu do sistema inquisitivo, revelou-se como instrumento tecnicamente incapaz de oferecer um julgamento justo nas esferas religiosa, civil e penal. Com efeito, a falta de denúncia formal, com todas as circunstâncias do fato típico, e a justa causa impossibilitava ao 
Revista da Seção Judiciária do Rio de Janeiro

imputado oferecer sua defesa plena e convenientemente, além disso, "a prevenção criada no espírito de do inquisidor não Ihe permite um julgamento psicologicamente imparcial" (TORNAGHI, 1980, p. 16).

Neste contexto, o aparato de repressão no sistema probatório inquisitorial tinha como meta a obtenção da "verdade real" a todo custo, ainda que com o emprego da tortura para se extrair a confissão do imputado. É por isso que a confissão dos imputados era extremamente necessária para o sistema inquisitório para justificar a condenação, como destaca Moura (1994, p. 12):

A obstinação da Inquisição em alcançar uma suposta verdade a partir da
tortura representou, em verdade, um retrocesso em matéria da prova, já
que conduzida muitas vezes à condenação de um inocente, que não
suportava o tormento, ou então à absolvição daquele que demonstrava
maior resistência ao suplício.

Por outro lado, com as ideias iluministas na seara penal no Século XVIII, as formalidades do sistema inquisitivo são transformadas para atos processuais que devem obedecer a uma sequência lógica, com determinadas formas já estabelecidas previamente à Lei. Essa sistematização transformou a fisionomia da persecução penal, já que o juiz deixa suas funções investigativas para se colocar como um árbitro imparcial entre acusação e defesa, em uma relação processual, ao menos, em tese, como afirma Pimenta Bueno (1959, p. 9):

A vitória da Revolução Francesa e dos princípios humanitários de BECCARIA trouxe procedimento acusatório, o réu passou a ser sujeito de direitos processuais. o juiz se despiu de sua funções persecutórias para colocar-se como árbitro imparcial entre acusação e a defesa. (sic)

Para a doutrina processualista dominante, não se confundem as tipologias dos sistemas processuais inquisitivo e acusatório quanto aos aspectos jurídicos e históricos. Por sistema de modelo processual acusatório entende-se aquele que é fundado na igualdade entre as partes, oralidade e publicidade dos atos. Além disso, a formação da prova em contraditório faz-se embasada na neutralidade e na livre 
Revista da Seção Judiciária do Rio de Janeiro

convicção do juiz para avaliar a prova com racionalidade. Por outro lado, o sistema inquisitivo se caracteriza pela identidade do juiz e do acusador no mesmo sujeito, pelo segredo dos atos e por sistema de provas privilegiadas ou legais.

Portanto, como já mencionado, por questões condicionantes históricas, está sedimentado na doutrina que o processo inquisitivo apresenta as características: secreto, escrito e não contraditório. As funções de acusar, de defender e de julgar encontram-se no mesmo órgão, que é o julgador que inicia o processo, colhe as provas e profere a decisão final. Assim, o sistema de persecução penal inquisitivo não reconhece a paridade de armas entres as partes e as garantias fundamentais da defesa ao imputado, o qual é tratado como um mero objeto do processo, ao ponto de para obter a confissão, rainha das provas, ser admitida. Por outro lado, no processo acusatório, as partes, acusação e acusado, encontram-se em situação de igualdade, com as garantias da imparcialidade do juiz, do contraditório e da publicidade.

Entretanto, Bettiol e Bettiol (2008, p. 163) fazem a observação de que "tal é a modelística abstrata. Em concreto nenhum modelo se apresenta historicamente no estado puro". De fato, é possível que, a rigor, as características de cada sistema de persecução penal deixem de apresentar suas peculiaridades próprias, de formas estanques e individualizadas.

Por essa razão, esses modelos são abstrações, não se pode afirmar que existem ou existiram os sistemas de persecução penal acusatórios ou inquisitivos de forma pura na sua estrutura. Percebe-se uma alternância e combinações das características dos sistemas de processo penal. Os sistemas de persecução penal são reflexo direto entre o cidadão e o modelo de Estado dentro de uma concepção liberdade e o direito de punir.

Como visto, há uma carga ideológica e emotiva para a distinção entre os sistemas de persecução penal acusatório e inquisitivo. A busca pela prova na persecução penal no sistema acusatório é estabelecida por parâmetros alicerçados 
Revista da Seção Judiciária do Rio de Janeiro

nas garantias processuais. Por outro lado, o sistema inquisitivo seria caracterizado por uma conotação negativa, que visava valores de defesa da sociedade com supressão de garantias constitucionais. Nesta perspectiva, é possível questionar a produção nos sistemas processuais penais na "busca da verdade real" para legitimação do jus puniendi estatal.

\section{A PRODUÇÃO DA PROVA NOS SISTEMAS INQUISITIVO E CONTRADITÓRIO}

Os sistemas de persecução penal têm uma íntima relação com o regramento da prova penal. Com efeito, no sistema inquisitivo, a matéria probatória é pouco regulamentada para "a busca da verdade real", sendo é admitida qualquer meio de provas para a imputação do fato típico ao agente, ao contrário do que acontece no sistema acusatório em que a atividade probatória é objeto de uma dogmática jurídica cuidadosa e minuciosa.

Como lembra Paolo Tonini (2002, p. 16-17), o princípio da autoridade fundamenta o sistema inquisitório, uma vez que confere amplos poderes ao sujeito inquisidor na busca das fontes de provas. De fato, o inquisidor acumula todas as funções processuais, atuando, ao mesmo tempo, no curso da persecução penal como juiz, acusador e defensor do imputado, o que são atribuídos amplos poderes para a investigação, a admissão, a produção e a valoração da prova. Diante desse contexto, não há instrumentos de controle na produção da prova, já que qualquer prova produzida é permitida sua entrada no processo para possibilitar ao "juiz inquisidor" o acertamento da verdade. Por outro lado, o sistema acusatório fundamenta-se pelo princípio dialético no acertamento da verdade, na distribuição das funções processuais e na imparcialidade do juiz, o qual está incumbido em decidir com fulcro no acervo probatório trazido pelas partes em contraditório.

Na mesma linha pensamento, Antonio Magalhães Gomes Filho (2008, p. 251) faz uma importante distinção entre o sistema de persecução penal inquisitório e 
Revista da Seção Judiciária do Rio de Janeiro

contraditório no espectro dos métodos de obtenção da prova para a descoberta da verdade sobre os fatos:

No método inquisitório a pesquisa dos fatos é conduzida unilateralmente, com o propósito de confirmar, a todo preço e custo, uma hipótese de verdade previamente estabelecida pelo inquisidor, o que traz em si grave vício epistemológico. Ao contrário, o sistema informado pelo contraditório, permitindo a cada uma das partes apresentar provas contrárias para trazer elementos de confronto em relação às provas do adversário, enriquece-se o material probatório à disposição do juiz, aumentando a base cognitiva para o estabelecimento da verdade sobre os fatos.

Por essa perspectiva, a doutrina jurídica sustenta que a regulamentação é mais específica em matéria probatória na persecução penal do sistema acusatório, que funciona como instrumento de controles epistêmicos para os agentes públicos na marcha do processo. Portanto, a prova vai legitimar o processo na busca pela verdade no aspecto demonstrativo, o que é um dos pilares do sistema de persecução penal acusatório, em que partes são livres para produzirem as provas licita.

É possível inferir que há uma íntima ligação sob o prisma das formas de Estado com os sistemas processuais penais. Desse modo, fica claro que o processo inquisitivo é ligado aos regimes autoritários, enquanto o processo acusatório é a expressão do Estado liberal-democrático. Essa relação da natureza do Estado se assemelha à concentração de poder nas mãos de um único sujeito, nos Regimes Absolutistas. Em contrapartida, no processo penal acusatório tem o princípio da separação dos poderes do Estado, que, em tese, impede a concentração de poder, 0 que evita o abuso (BADARÓ, 2003, p. 107).

Como decorrência, sem dúvidas que o processo penal no sistema acusatório é um instrumento epistemológico que pretende ser construído no conhecimento racional, através de normas, as quais são as premissas para os juízes. Assim, verificar a constatação da infração penal, obriga o dever de punir, mas é preciso legitimar o exercício do poder estatal, que, por outro lado, o próprio Estado impõe limites aos atores da persecução penal no exercício de suas funções contra 
Revista da Seção Judiciária do Rio de Janeiro

arbitrariedades, dentre elas, a captação da prova que deve respeito aos direitos e às garantias fundamentais (PRADO, 2019, p. 38).

Com essas ponderações, portanto, existe uma nítida relação entre os sistemas de persecução penal e a atividade probatória. Desse modo, no sistema inquisitivo se caracteriza pela identidade do juiz e do acusador no mesmo sujeito, pelo segredo dos atos e por sistema de provas privilegiadas ou legais. Por outro lado, no sistema acusatório, a formação da prova dá-se em contraditório das partes e neutralidade para a livre convicção do juiz para julgar.

\section{A PROVA NO SISTEMA JURÍDICO DA COMMON LAW NA PERSECUÇÃO PENAL ADVERSARIAL}

O sistema jurídico conhecido como Common Law foi elaborado paulatinamente na Inglaterra, a partir do Século XII, sendo fundamentado na jurisdição real das decisões, o que possibilitou juízes profissionais, com formação prática, e a introdução de um mecanismo de recursos aos precedentes (cases).

Note-se que a fonte de provas, neste sistema jurídico, eram os costumes locais anglo-saxônicos, costumes das cidades e costumes dos mercadores. Diante disso, em matéria criminal, os reis tinham juízes que reuniam as cortes locais e julgavam os casos em pauta, o que conferiu a unidade ao Common Law. Neste contexto, a forma de atuação dos instrumentos de resolução de litígios adotados pela Inglaterra afastou o direito inglês do modelo romano-canônico que imperava na Europa Continental, uma vez que o júri substituiu os juízos de Deus (PRADO, 2006, p 88-89):

No campo específico do processo penal, desde o Século XII assoma a importância do júri. O Júri inicialmente foi disposto não só para julgar a causa, mas, antes, para denunciar os crimes mais graves (Grand Jury), não se entregando a acusação pública, em matéria criminal, a um específico funcionário, juiz ou membro do Ministério Público, como no continente. (PRADO, 2006, p. 88). 
Revista da Seção Judiciária do Rio de Janeiro

Com pensamento semelhante, Michele Taruffo (2013, p. 15) faz uma advertência de que não é rigorosamente confiável do ponto de vista metodológico, fazer uma correlação de que o modelo do processo de Common Law seria baseado essencialmente na oralidade, enquanto o processo da Civil Law ser essencialmente na escrita. Para o autor italiano, essa distinção no plano da comparação tradicional de modelos processuais, nunca representou uma contraposição principiológica, uma vez que o emprego de provas escritas é muito frequente na Common Law, embora haja diferenças aos aspectos do direito probatório. Por outro lado, no processo Civil Law existem elementos de debates na produção de provas orais em audiências e na previsão de decisões orais em vários casos.

O sistema jurídico inglês, produção de provas adversariais, a partir do século XVIII, década de 1730, passou a admitir advogados, defensores técnicos, nos julgamentos criminais, já que havia um desequilíbrio entre as partes. Isso porque, o acusado não tinha direito à defesa técnica, o que apresentava uma problemática para a igualdade material, já que o réu tinha que fazer a sua própria defesa. $\mathrm{A}$ justificativa era que o imputado conhecia os fatos melhor do que qualquer defensor $\mathrm{e}$ as questões de direito ficam a cargo do juiz da Coroa. Por isso, esse modelo era chamado de acusado que fala (accused speaks). (MALAN, 2009, p. 10-13).

Desse modo, o sistema probatório adversarial foi construído na perspectiva de modelo de Estado Liberal. Ainda cabe destacar que havia uma disparidade entre os imputados, sendo classificados de acordo com a infração penal de natureza grave, os quais eram proibidos de ter assistência de advogado, mas ter apenas testemunhas para sua defesa. Cabia ao próprio acusado exercer sua defesa, enquanto as vítimas podiam ajuizar a ação penal e contratar advogados para representá-las (MALAN, 2009, p. 7-10).

Nesta perspectiva, Geraldo Prado (2006, p. 90) assinala que a instituição da ação popular, a postura da imparcialidade e a equidistância do júri (passividade) 
Revista da Seção Judiciária do Rio de Janeiro

compartilham que o processo de persecução penal anglo-saxão tenha conservado na sua essência um sistema de tipicamente acusatório:

O sistema de persecução penal adversarial é caracterizado pelo impulso das partes, na escolha e apresentação dos elementos probatórios para formar o convencimento do julgador. As partes são os protagonistas do processo criminal, o que vai atingir o poder instrutório dos juízes na formação da prova. Com efeito, os elementos essenciais que compõem o processo adversarial: julgador neutro e passivo, iniciativa instrutória das partes e ambiente forense altamente neutro.

Ainda segundo, Michele Taruffo (2013, p. 16-17) também a contraposição entre processo adversarial ser típico dos ordenamentos de common law, e processo inquisitorial se típico dos sistemas de civil law, está superada, além de ser substancialmente inútil e completamente duvidoso do ponto de vista científico fazer essa polarização. Atualmente, o tradicional modelo de processo adversarial é caracterizado pela presença ativa do juiz, sobretudo no plano da gestão do procedimento e tem poderes autônomos de iniciativa probatória.

Por conseguinte, o sistema adversarial tem a proposta de garantir, em tese, uma relativa igualdade formal entre as partes na persecução penal, já que tem como característica ser um processo de partes na captação da prova com a finalidade de convencimento ao juiz no julgamento. Entretanto, a igualdade no plano formal não representa a igualdade para os imputados em geral, posto que as desigualdades econômicas vão proporcionar diferentes defesas técnicas para a colheita da prova.

Mesmo assim, a doutrina anglo-americana defende a legitimidade do sistema adversarial como sendo um modelo mais adequado para a obtenção da verdade, uma vez que proporciona às partes melhores condições de apresentar seus acervos probatórios, além dos seguintes argumentos:

(i)Fornece às partes processuais os meios necessários para controlar o processo judicial, girando o julgamento em torno das questões propostas por elas, o que reforça os direitos individuais; (ii) torna as partes processuais mais propensas a aceitar o resultado do julgamento, pois elas se envolvem de forma íntima com o processo e têm oportunidades justas de apresentar 


\begin{abstract}
suas respectivas versões dos fatos; (iii) satisfaz também os interesses da sociedade como um todo, pois a passividade do julgador, ao impedir que ele aparente ser parcial, reforça a percepção social de um julgamento intrinsecamente justo; (iv) induz o advogado cujo cliente se encontra em situação de desvantagem a um maior empenho na obtenção de elementos de provas que revertam tal desvantagem; ( $v$ ) minimiza os riscos de suspeição do julgador, ao afastá-lo da gestão probatória e tornar a adjudicação neutra do caso sua única distribuição; (vi) evita que um mesmo sujeito processual de depare com responsabilidades conflitante entre si, ao prever uma clara repartição de funções entre os sujeitos do processo; (vii) reafirma a individualidade humana, proporcionando à partes um foro neutro e independente onde seus anseios serão ouvidos e considerados, ainda que sejam contrários aos interesses do Estado. (MALAN, 2009, p. 24).
\end{abstract}

Diante desse aspecto, no modelo de persecução penal acusatório o empate se dá entre o Estado puniendi e o imputado, enquanto no adversarial está entre o Estado persecutio criminis em juízo contra o imputado para aplicação da lei penal.

No sistema adversarial, o advogado do imputado tem uma função proativa na dinâmica da persecução penal, essa atividade é bem delineada por Diogo Malan (2009, p. 19) ao argumento de que "a ideia central é afastar o julgador da gestão da probatória na contenda, forçando as partes processuais a investigar propor os elementos de prova que entendam mais persuasivos". Portanto, é possível inferir que as partes travam uma batalha jurídica dialética na seara probatória em paridade de armas, ao menos em tese.

As partes são os protagonistas da persecução penal na colheita de provas com o objetivo de influenciar o juiz com suas teses: "ganha quem argumenta melhor, dadas as armas disponíveis aos contendores. As regras do jogo são dirigidas às partes. Ganha quem joga melhor" (VIEIRA, 2014, p. 156). Nesta visão, as partes buscam atingir decisão jurídica favorável dentro do processo justo e equitativo, porquanto a defesa produz suas provas por autoridade própria, já que há o direito à paridade de armas.

Geraldo Prado (2019, p. 72) sustenta que os modelos adversariais de processo penal têm aplicação prática no sistema de persecução brasileiro "porque são redutoras de complexidade dos mandamentos constitucionais do direito ao 
Revista da Seção Judiciária do Rio de Janeiro

conhecimento da acusação (com a ciência de meios e fontes de provas existentes), tutela contra a autoincriminação compulsória, direito à paridade de armas, à audiência e à prova."

Assim, para evitar excessos discricionários na produção da prova, torna-se importante nesse modelo probatório de persecução penal a iniciativa probatória das partes, o que leva a neutralidade e a imparcialidade do julgador. Por esse motivo, no sistema processual adversarial, o juiz faz o controle epistemológico da "busca da verdade", com racionalidade, que vai legitimar e justificar a absolvição ou condenação do réu.

\section{CONSIDERAÇÕES FINAIS}

Após esse breve estudo acerca das relações entre os sistemas probatórios de persecução penal e a busca pela verdade na Idade Média na Europa continental e na Inglaterra, conclui-se que a atividade probatória, ao longo desse período histórico, foi, pouco a pouco, se afastando do misticismo das órdalias, de tradição do direito germânico, até chegar à racionalidade na produção da prova com as ideias liberais da filosofia Iluminista na Idade Moderna com métodos das colheitas das provas para a resolução de conflitos judiciais na seara criminal.

Ficou evidenciado que para a maioria da doutrina processualista, com a publicação da Magna Charta Libertatum tem-se a gênese do processo penal moderno, ainda que de forma embrionária, com a cláusula do devido processo legal. A partir dessa cláusula, consagrou-se o habeas corpus, o tribunal do júri para dirimir as controvérsias jurídicas, bem como, inúmeros princípios da persecução penal são derivados, dentre eles, a reserva e jurisdição, o princípio do contraditório, da presunção de inocência.

Constatou-se que há uma carga ideológica e emotiva para diferenciar os sistemas de persecução penal acusatório e inquisitivo. Isso porque, embora esses 
Revista da Seção Judiciária do Rio de Janeiro

sistemas possuem suas peculiaridades próprias, não há um sistema puro, uma vez que as características deles na "busca da verdade real" são abstrações com alternâncias e combinações próprias de cada um deles.

No que diz respeito ao sistema jurídico da Common Law, o qual foi elaborado paulatinamente na Inglaterra, a partir do Século XII, possibilitou o surgimento de juízes profissionais, com formação prática, e a introdução de um mecanismo de recursos precedentes (cases). Destaque-se ainda que a fonte desse sistema jurídico era baseado nos costumes locais anglo-saxônicos, costumes das cidades e costumes dos mercadores. Diante disso, a forma de atuação dos instrumentos de resolução de litígios adotados pela Inglaterra afastou o direito inglês do modelo romano-canônico que imperava na Europa Continental, posto que a instituição júri substituiu os duelos e as ordálias.

Por fim, considerando essas breves linhas históricas em torno dos sistemas probatórios na Idade Média, é de se ver que a produção da prova é um fenômeno que varia no tempo e no espaço, sendo intimamente ligada por circunstâncias culturais, que influenciam os sistemas jurídicos da Civil Law e da Common Law, para demonstrar a realidade fática, mas sempre voltada à formação do convencimento do julgador e diretamente vinculada aos sistemas persecução penal. Além disso, o mito da "verdade real" em termos absolutos é algo inatingível, seja qual for o sistema probatório de persecução penal, até os dias atuais. Porém, isso não significa que é impossível que se possa buscar o acertamento do processo para condenar um culpado ou absolver um inocente para uma decisão justa. 
Revista da Seção Judiciária do Rio de Janeiro

\section{REFERÊNCIAS}

AQUINO, Rubim Santos Leão de; FRANCO, Denize de Azevedo; LOPES, Oscar Guilherme Pahl Campos. História das Sociedades: das comunidades primitivas às sociedades medievais. Rio de Janeiro: Editora ao Livro Técnico, 1980.

ARRUDA, José Jobson de A. História Antiga e Medieval. 9. ed. São Paulo: Ática, 1986.

BADARÓ, Gustavo Henrique Righi Ivahy. Ônus da prova no processo penal. São Paulo: Revista dos Tribunais, 2003.

BETTIOL, Giuseppe; BETTIOL, Rodolfo. Instituições de direito e processo penal. São Paulo: Editora Pillares, 2008.

BUENO, José Antônio Pimenta. Apontamentos sobre o processo criminal brasileiro. São Paulo: Revista dos Tribunais, 1959.

CARVALHO, Gustavo Grandinetti Castanho de. Processo Penal e constituição: princípios constitucionais do processo penal. 3. ed. reesc. e ampl. Rio de Janeiro: Lumen Juris, 2004.

CASTRO, Flávia Lages de. História do Direito Geral e do Brasil. Lumen Juris: Rio de Janeiro: 2006.

FOUCAULT, Michel. A verdade e as formas jurídicas. Rio de Janeiro: NAU, 2002.

GOFF, Jacques Le. La civilización del occidente medieval. Barcelona: Editorial Paidós, 1999.

GOMES FILHO, Antonio Magalhães. Provas - Lei 11.690, de 09.06.2008. In: MOURA, Maria Thereza Rocha de Assis (org.). As reformas no processo penal: as novas Leis de 2008 e os projetos de reforma. São Paulo: Revista dos Tribunais, 2008.

GRINOVER, Ada Pellegrini. Liberdades públicas e processo penal: as interceptações telefônicas. 2. ed. atual. São Paulo: Revista dos Tribunais, 1982.

Julgamento antecipado da lide direito ao processo. In o processo e sua unidade. São Paulo: Saraiva, 1978.

GROSSI, Paolo. A ordem jurídica medieval. São Paulo: WMF Martins Fontes, 2014. 
Revista da Seção Judiciária do Rio de Janeiro

HESPANHA, António Manuel. A Cultura Jurídica Europeia: síntese de um milénio. Coimbra: Almedina, 2012.

KHALED JUNIOR, Salah Hassan. A busca da verdade no processo penal: para além da ambição inquisitorial. 2. ed. Belo Horizonte: Casa do Direito; Letramento, 2016.

MACHADO, Antonio Alberto. Teoria Geral do Processo Penal. São Paulo: Atlas, 2009.

MALAN, Diogo Rudge. Direito ao confronto no processo penal. Rio de janeiro: Lumen Juris, 2009.

MOURA, Maria Thereza Rocha de Assis. A prova por indícios no processo penal. São Paulo: Saraiva, 1994.

PAULO, Alexandre Ribas de. O discurso jurídico-penal iluminista no direito criminal do império brasileiro. In: DAL RI JÚNIOR, Arno; SONTAG, Alexander; PAULO, Alexandre Ribas; CASTRO, Alexander de. Iluminismo e direito penal. Florianópolis:

Fundação Boiteux, 2009.

PRADO, Geraldo. A cadeia de custódia da prova no processo penal. São Paulo: Marcial Pons, 2019.

. Sistema acusatório: a conformidade constitucional das leis processuais penais. 4. ed. Rio de Janeiro: Lumen Juris, 2006.

ROBERTO, Welton. Paridade de armas no processo penal. Belo Horizonte: Fórum, 2011.

ROSA, Alexandre Morais. Decisão Penal: a bricolage de significante. Rio de Janeiro: Lumin Juris, 2004.

SZNICK, Valdir. Princípios de defesa na Constituição. São Paulo: Iglu, 2002.

TARUFFO, Michele. Uma simples verdade: O Juiz e a construção dos fatos. São Paulo: Marcial Pons, 2016.

2013.

. Processo Civil Comparado: Ensaios. São Paulo: Marcial Pons,

TONINI, Paolo. A prova no processo penal italiano. São Paulo: Editora Revista dos Tribunais, 2002. 
Revista da Seção Judiciária do Rio de Janeiro

TORNAGHI, Hélio Bastos. Curso de processo penal. 7. ed. São Paulo: Saraiva, 1980.

TUCCI, Rogério Lauria. Teoria do direito processual penal: jurisdição, ação e processo penal (estudo sistemático). São Paulo: Editora Revista dos Tribunais, 2002.

VIEIRA, Renato Stanziola. Paridade de armas no processo penal. 1. ed. Brasília: Gazeta Jurídica, 2014. 